\title{
MANAJEMEN LEMBAGA PENDIDIKAN ISLAM DALAM MENINGKATKAN PROFESIONALISME GURU DI SMP IT DARUSSALAM SRAGEN
}

\author{
Etik Kurniawati \\ STIT Madina Sragen \\ Email: etikkurniawati46@gmail.com
}

\begin{abstract}
Abstrac
To improve teacher competency in schools one way is through the management of Islamic education institutions that favor the improvement of teacher competencies. What is the supervision of Islamic education institutions in increasing the professionalism of teachers in the Darusalam Middle School Sragen. This study aims to describe the management plan of Islamic education institutions in enhancing the professionalism of teachers at the Darusalam Middle School in Sragen.. The research subjects were the Principal of the Middle School of Darussalam Darussalam Sragen, Deputy Head of Affairs (curriculum, student affairs, finance, facilities), TU Staff and Teachers. Data obtained through observation, interviews, and documentation. After collecting data, presenting data, and analyzing data. The data shows that the increase in the competence of teachers at the IT Darussalam Middle School can be achieved through two things, namely the efforts of teachers and the participation of educational institutions. The efforts of teachers in order to improve their competence through four things, include: pedagogical, personal, social and professional competencies.
\end{abstract}

Key Word: Management of Islamic Education Institutions, Teacher Professionalism

\begin{abstract}
Abstrak
Meningkatkan kompetensi guru di sekolah salah satu caranya adalah melalui manajemen lembaga pendidikan Islam yang berpihak pada peningkatan kompetensi guru. Penelitian ini bertujuan Mendeskripsikan perencanaan manajemen lembaga pendidikan Islam dalam meningkatkan profesionalisme guru di SMP IT Darusalam Sragen. Subjek penelitian adalah Kepala Sekolah SMP IT Darussalam Sragen, Wakil Kepala urusan (kurikulum, kesiswaan, keuangan, sarana prasarana), Staf TU dan Guru. Data diperoleh melalui observasi, wawancara, dan dokumentasi. Setelah melakukan pengumpulan data, penyajian data, dan analisis data diperoleh data bahwa peningkatan kompetensi guru SMP IT Darussalam dapat diraih melalui dua hal yaitu dengan usaha dari guru dan peran serta lembaga pendidikan. Upaya guru dalam rangka meningkatkan kompetensinya melalui empat hal, meliputi: kompetensi pedagogik, pribadi, sosial dan profesional.
\end{abstract}

Kata Kunci: Manajemen Lembaga Pendidikan Islam, Profesionalisme Guru PROGRESS - Volume 7, No. 1, Juni 2019 


\section{A. PENDAhULUAN}

Salah satu tempat yang dapat digunakan sebagai sarana mencerdaskan dan memajukan kehidupan bangsa ialah melalui lembaga pendidikan. Dalam hal ini adalah lembaga pendidikan Islam. Lembaga pendidikan Islam merupakan salah satu institusi sosial yang memiliki peran strategis dalam pembinaan kepribadian anak. Di dalamnya terjadi proses pembudayaan bagi anak-anak (akulturasi). Transformasi kebudayaan berlangsung melalui pembelajaran sesuai kurikulum yang berisikan berbagai bidang ilmu pengetahuan dan nilai-nilai yang berlaku di masyarakat. Fungsi pendidikan sebagai institusi sosial yang menjamin kelangsungan hidup generasi muda suatu bangsa. Baik pendidikan di sekolah, keluarga maupun di masyarakat pada intinya untuk mengalihkan, dan mengembangkan kebudayaan agar kehidupan masyarakat survive sesuai dengan cita-cita bangsanya.

Di tengah maraknya isu bahwa sekolah Islam merupakan bibit pembelajaran radikalisme seperti yang dikutip di Majalah Tempo pada edisi 19-25 Juni 2017 lalu, ternyata Sekolah Islam Terpadu (SIT) saat ini menjadi salah satu lembaga pendidikan yang mendapat sambutan luas dari umat Islam indonesia. Hal tersebut dibuktikan oleh beberapa hal, yaitu pertama dengan semakin banyaknya orang tua yang menyekolahkan anak-anak mereka di berbagai jenjang SIT, mulai TK, SD, SMP, hingga SMA. Kualitas dari para guru dan semua staff yang mendukung di sekolah Islam. Tidak hanya teori yang dibagi oleh para guru, tapi juga tauladan langsung yang dicontohkan oleh para guru dan staff dalam setiap aktivitas mereka di sekolah. Hal ini yang bisa membuat para orang tua yang menitipkan anaknya di sekolah Islam bisa tenang dan percaya bahwa anak-anak mereka akan menjadi anak yang 
tidak hanya cerdas di akademis tapi juga cerdas di akhlaq. Kedua, Sekolah islam sangat besar diminati oleh umat Islam karena selain menggunakan kurikulum dari Kemendikbud, Sekolah Islam juga memiliki keutamaan dengan pengembangan kurikulum yang dibuatnya. Tidak hanya bidang akademis yang coba ditonjolkan, tapi juga bidang lainnya seperti pemahaman agama yang baik, pendidikan karakter, kemampuan untuk menguasai bahasa asing lebih banyak, di sekolah Islam memperlajari Bahasa Arab juga selain Bahasa Inggris, serta berbagai kompetensi di luar bidang akademis lainnya.

Perkembangan lembaga pendidikan Islam ini tentu saja menjadi angin segar bagi masyarakat Muslim pada khususnya. Lembaga pendidikan Islam diharapkan mampu memainkan peranan dalam kehidupan yang mengalami perubahan. Pendidikan Islam harus mampu membekali pengetahuan dan keterampilan kepada peserta didik agar bisa menghadapi tantangan zaman. ${ }^{1}$ Selain itu, apabila suatu lembaga pendidikan dikelola oleh orang-orang yang berkompeten di bidangnya, maka tujuan pendidikan yang diharapkan dapat tercapai secara lebih efektif dan efisien. Salah satu sumber daya manusia yang berperan penting di sekolah ialah guru. Dalam bahasa jawa, guru merupakan orang yang harus digugu dan ditiru, karena guru merupakan orang yang memiliki kharisma atau wibawa sehingga perlu untuk ditiru dan diteladani. $^{2}$ Selain itu, guru merupakan sosok pahlawan tanpa tanda jasa yang mana dari seorang guru, lahirlah generasi-generasi penerus perjuangan bangsa indonesia.

\footnotetext{
${ }^{1}$ Iqbal Fahri, Madrasah Unggulan dalam Tinjauan (Artikel PDF)

${ }^{2}$ Sri Hartati, Kompetensi dan Profesionalisme Guru, Al-Wafa' Jurnal Pendidikan Sosial dan Keagamaan, 2015/Vol.1, hlm. 1.
}

PROGRESS - Volume 7, No. 1, Juni 2019 
Guru yang profesional harus memiliki kompetensi dalam mengajar, hal ini mengingat begitu pentingnya tugas dan tanggung jawab guru dalam mensukseskan pendidikan di sekolah. Kompetensikompetensi yang harus dimiliki oleh seorang guru tersebut, diantaranya ialah kompetensi pedagogik, kompetensi kepribadian, kompetensi profesional dan kompetensi sosial. Keempat kompetensi tersebut tidak dapat dipisahkan dan saling berhubungan satu sama lain. ${ }^{3}$ Kompetensi guru merupakan salah satu faktor yang mempengaruhi tercapainya tujuan pembelajaran dan pendidikan di sekolah. Guru yang berkompeten akan berpengaruh terhadap kualitas output pendidikan yang dihasilkan. Kualitas output pendidikan ini, dapat dilihat dari kualitas lulusan yang dihasilkan, berupa nilai yang dicapai peserta didik dan dampak pengiring saat peserta didik terjun di masyarakat. Selain itu, guru juga merupakan salah satu faktor yang menentukan produktifitas pendidikan di sekolah. Agar produktifitas pendidikan di sekolah dapat meningkat, maka rekrutmen guru harus dilakukan secara selektif, sehingga guru dapat bekerja secara profesional dalam menjalankan tugasnya.

Berkaitan dengan profesionalisme guru, fakta di lapangan menunjukkan bahwa masih terdapat guru yang belum memenuhi kualifikasi akademik sesuai dengan Undang-Undang. Kualifikasi akademik merupakan tingkat pendidikan minimal yang harus dipenuhi guru yang dibuktikan dengan ijazah atau sertifikat keahlian yang relevan sesuai ketentuan yang berlaku. ${ }^{4}$ Kenyataan di lapangan menunjukkan bahwa masih banyak dijumpai sarjana yang background pendidikannya non keguruan, bahkan masih terdapat guru yang belum lulus sarjana

\footnotetext{
${ }^{3}$ Syamsul Ma'arif, Guru Profesional Harapan..., hlm. 15.

${ }^{4}$ Syamsul Ma'arif, Guru Profesional Harapan..., hlm. 16.
} 
yang sudah mengajar di sekolahan. Hal ini dapat menimbulkan permasalahan baru, seperti guru belum optimal dalam menyampaikan pelajaran kepada peserta didik sehingga dapat menurunkan kualitas output pendidikan yang dihasilkan. ${ }^{5}$

Hal serupa juga dialami oleh lembaga pendidikan Islam seperti SMP IT Darussalam Sragen, hal ini tentunya merupakan problem yang harus ditangani secara serius dalam dunia pendidikan. SMP IT Darussalam Sragen merupakan salah satu lembaga pendidikan Islam terpadu di bawah nauangan Yayasan Pendidikan Darussalam yang berada di wilayah Sragen. Walaupun tergolong baru, namun lembaga pendidikan tersebut telah memperoleh banyak prestasi, salah satunya adalah bidang tahfidz. Namun demikian, di sekolah tersebut masih terdapat guru yang belum linear. Padahal seperti yang dijelaskan diatas bahwa kualitas hasil belajar peserta didik salah satunya ditentukan oleh kompetensi guru dalam mengajar. Hal ini mengingat bahwa gurulah yang sering bertatap muka dengan peserta didik dan bertugas untuk mengajar, mendidik dan membimbing peserta didiknya.

Persoalan mengenai kompetensi guru diatas, menuntut peran lembaga pendidikan Islam untuk mengembangkan dan meningkatkan kualitas para guru yang ada di sekolah sehingga dapat meningkatkan kinerja kearah profesionalisme yang diharapkan melalui pendidikan dan pelatihan. Sebagai tulang punggung generasi Islam dalam memperdalam pengetahuan umum dan agama, lembaga pendidikan Islam perlu adanya renovasi ulang baik dari segi manajemen dalam meningkatkan profesionalisme guru. Dengan terlaksananya manajemen yang baik, maka kualitas lulusan akan tercapai dengan memuaskan dan baik pula.

\footnotetext{
${ }^{5}$ Warsiyah, Manajemen Mutu dalam.., hlm.3.
} 
Dalam konteks ini, diperlukan penerapan fungsi-fungsi manajemen, dimana proses manajemen merupakan aktivitas yang melingkar, mulai dari perencanaan, pengorganisasian, pengarahan, sampai dengan pengawasan, yang memungkinkan program pengajaran berjalan dengan baik, sehingga berbasis pada kompetensi dan bermuara kepada kualitas pelayanan yang baik dan kualitas lulusan yang dibanggakan. Para manajer lembaga pendidikan mengintegrasikan dan mengkoordinasikan kegiatan-kegiatan dan pekerjaan dari sejumlah orang yang terlibat dalam proses manajerial secara profesional. Untuk itu setiap pengelola pendidikan harus menyadari bahwa keterampilan manajerial sangat penting artinya dalam memajukan lembaga pendidikan islam terutama meningkatkan produktivitas pendidikan.

Bergulirnya kebijakan otonomi bidang pendidikan merupakan peluang bagi pemberdayaan lembaga pendidikan. Hal ini memberikan peluang bagi restrukturisasi lembaga pendidikan, baik bidang manajemen maupun sumber daya manusianya. Pelaksanaan otonomi pendidikan yang paling pokok adalah terletak pada pemberian otonomi kepada pengelola lembaga pendidikan. Isu pendidikan nasional yang berkaitan dengan kualitas atau mutu, banyak direspon para pengelola pendidikan sesuai dengan kewenangan dan kemampuannya dalam mengelola lembaga pendidikannya. Maka penerapan sistem manajemen sangat menentukan arah perbaikan sebuah lembaga pendidikan, khususnya peningkatan kualitas pembelajaran semakin diberikannya otonomi, namun sejurus dengan kebijakan yang telah digulirkan pada tataran realitasnya cara pimpinan lembaga pendidikan merespon kebijakan Pendidikan Nasional ini sangat beragam dan cenderung lamban, terutama dalam sistem manajemen yang belum sepenuhnya 
berorientasi pada peningkatan kualitas, masih sukarnya lembaga pendidikan Islam dalam meningkatkan pembiayaan, kecilnya dukungan masyarakat, banyaknya pengaruh lingkungan bagi pembinaan kesiswaan, target pelaksanaan kurikulum yang terlalu berat, pembinaan personil guru cenderung masih kurang, karena rendahnya biaya pendidikan. Jika di pahami lebih mendalam, pengelolaan organisasi pendidikan sesungguhnya tidak boleh asal-asalan, karena kehadiran organisasi pendidikan merupakan tuntutan moderenisasi, kemajuan sains dan teknologi dalam rangka mengoptimalkan pembinaan potensi pribadi manusia sebagai makhluk yang berbudaya. ${ }^{6}$

Berdasarkan permasalahan tersebut diatas peneliti tertarik untuk melakukan penelitian terkait manajemen lembaga pendidikan Islam dalam meningkatkan profesionalisme guru di SMP IT Darussalam Sragen. Dari pengamatan peneliti manajemen lembaga pendidikan di SMP IT Darussalam Sragen sudah mulai memperhatikan kualitas para guru, dengan mengadakan supervisi pada guru, mengadakan kegiatan pelatihan, serta upaya-upaya lain untuk mengembangkan kualitas guru, oleh karena itu harus diimbangi oleh kualitas dari pengelolaan manajemen di lembaga pendidikan Islam itu sendiri yang meliputi empat hal pokok yaitu: manajemen kurikulum, manajemen sumber daya manusia, manajemen kesiswaan, manajemen keuangan dan manajemen sarana prasarana sekolah. Keempat hal ini menurut peneliti terkait langsung dengan peningkatan profesionalisme guru. Dari sinilah peneliti berasumsi bahwa manajemen lembaga pendidikan Islam di SMP IT Darussalam Sragen sudah menerapkan fungsi-fungsi manajemen yaitu yang meliputi perencanaan, pengorganisasian, pengarahan dan

${ }^{6}$ Muhaimin, Eksistensi Madrasah sebagai madrasah Umum yang berciri khas Islam (Malang: IAIN Tarbiyah, 1997), hlm. 76.

PROGRESS - Volume 7, No. 1, Juni 2019 
pengawasan yang akan berpengaruh terhadap peningkatan profesioalisme para guru. Dengan asumsi tersebut, maka peneliti akan memfokuskan penelitian ini mengenai "Manajemen Lembaga Pendidikan Islam Dalam Meningkatkan Profesionalisme Guru di SMP IT Darussalam Sragen".

\section{B. KAJIAN TEORITIS}

\section{Manajemen Lembaga Pendidikan Islam}

Manajemen berasal dari bahasa Latin, yaitu dari asal kata manus yang berarti tangan dan agere yang berarti melakukan. Kata-kata itu digabung menjadi kata kerja managere yang artinya menangani. Managere diterjemahkan ke dalam bahasa Inggris dalam bentuk kata kerja to manage, dengankata benda management, dan manager untuk orang yang melakukan kegiatan manajemen. Akhirnya, managemen diterjemahkan ke dalam bahasa Indonesia menjadi manajemen atau pengelolaan. $^{7}$

Manajemen pada hakikatnya membutuhkan interaksi dan sinergisitas antar komponen organisasi dengan menggerakkan sumber daya yang dimiliki, sehingga mampu mewujudkan harapan dan cita-cita organisasi. Sebagai suatu ilmu, manajemen memiliki objek studi, metode, strategi dan pendekatan sehingga dapat digunakan dan diterapkan dalam masyarakat.

Beberapa definisi menunjukkan bahwa manajemen merupakan suatu proses yang sistematis dalam melakukan kegiatan organisasi. Proses manajemen secara umum mengikuti langkah-langkah POAC (planning, organizing, actuating and controlling).

\footnotetext{
${ }^{7}$ Husaini Usman, Manajemen : Teori, Praktek dan Riset Pendidikan, Jakarta: Bumi Aksara 2009, hlm. 5
}

PROGRESS - Volume 7, No. 1, Juni 2019 


\section{Fungsi Manajemen Lembaga Pendidikan Islam}

Kegiatan manajemen sangat luas, sebab dimulai dari bagaimana menentukan arah masa depan, menciptakan kegiatan-kegiatan, mendorong terbinannya kerja sama antara sesama, serta mengawasi kegiatan dalam mencapai tujuan. Untuk mencapai tujuan tersebut maka diperlukan beberapa langkah diantaranya:

a. Perencanaan (Planning)

Perencanaan merupakan tindakan awal dalam aktivitas pada setiap organisasi. Karena itu, perencanaan akan menentukan adanya perbedaan kinerja satu organisasi dengan organisasi lain dalam pelaksanaan rencana untuk mencapai tujuan. Perencanaan merupakan proses menentukan apa yang seharusnya dicapai dan bagaimana mewujudkannya dalam kenyataan. Berarti di dalam perencanaan akan ditentukan apa yang akan dicapai dengan membuat rencana dan caracara melakukan rencana untuk mencapai tujuan yang ditetapkan. Terdapat tiga unsur pokok dalam kegiatan perencanaan yaitu: (1) pengumpulan data, (2) analisis fakta dan, (3) penyusunan rencana yang konkrit.

Sementara menurut Siagian suatu proses perencanaan harus dapat menjawab lima pertanyaan pokok, yaitu: (1) apa yang akan dikerjakan dalam satu kurun waktu tertentu? (2) siapa yang bertanggung jawab untuk melakukan dan kepada siapa bertanggung jawab? (3) prosedur, mekanisme dan metode kerja yang bagaimana yang akan diberlakukan dalam pelaksanaan kegiatan tersebut agar terintegrasi dengan baik? (4) adakah penjadwalan kegiatan yang jelas dan harus ditaati? (5) apa 
alasan yang benar-benar dipertanggung jawabkan tentang mengapa berbagai kegiatan harus dilaksanakan ${ }^{8}$

b. Pengorganisasian (Organizing)

Organisasi dalam bentuk apapun pada dasarnya terdiri dari sumber daya, proses manajemen yang jelas dan tujuan organisasi. Seluruh sumber daya yang dimiliki organisasi tersebut dimanfaatkan dalam proses manajemen secara terintegrasi dalam pencapaian tujuan organisasi. Pengorganisasian sumber daya merupakan fungsi manajemen yang kedua dan merupakan langkah strategis untuk mewujudkan suatu rencana organisasi. Menurut Winardi pengorganisasian ialah suatu proses di mana pekerjaan yang ada dibagi dalam komponen-komponen yang dapat ditangani dan aktivitasaktivitas mengkoordinasikan hasil yang dicapai untuk mencapai tujuan tertentu. ${ }^{9}$

Setiap lembaga pendidikan memerlukan pengorganisasian sumber daya manusia agar organisasinya dapat berjalan secara sistematis dan efisien. Walaupun pada kenyataannya, masih banyak lembaga pendidikan yang belum mengembangkan sistem pengorganisasian sumber daya manusia yang komprehensif, padahal pengorganisasian sumber daya manusia merupakan sesuatu yang penting dalam organisasi untuk menanggapi dengan baik dan tepat perubahan-perubahan yang terjadi pada lingkungan eksternal organisasi. Daya adaptabilitas organisasi pada perubahan lingkungan eksternal dapat dikembangkan melalui peningkatan kapasitas dan kompetensi sumber daya yang ada. Pengembangan sumber daya bermakna perwujudan tanggung jawab sosial suatu organisasi.

\footnotetext{
${ }^{8}$ Sondang. P. Siagian, Filsafat Administrasi (Jakarta: Gunung Agung, 1985), hlm. 70

${ }^{9}$ Winardi, Dasar, hlm. 91.
}

PROGRESS - Volume 7, No. 1, Juni 2019 
c. Pelaksanaan (Actuating)

Kegiatan pelaksanaan rencana merupakan kegiatan nyata yang dilakukan untuk memperbaiki atau meningkatkan kemampuan pendidik. Kegiatan pelaksanaan rencana merupakan kegiatan pemberian bantuan dari supervisor kepada pendidik, agar dapat terlaksana dengan efektif pelaksanaannya harus sesuai dengan perencanaan yang telah ditetapkan dan ada follow up untuk melihat keberhasilan proses dan hasil pelaksanaan manajemen.

Pada akhirnya manajer menyimpulkan hasil dengan melihat keinginan yang sebenarnya dicapai, kemudian menentukan bersama rencana menajerial yang akan datang baik berupa dorongan untuk meningkatkan hal-hal yang belum dikuasai pada tahap sebelumnya (proses belajar mengajar yang telah dilakukan) maupun keterampilanketrampilan yang perlu disempurnakan.

d. Pengawasan (Controlling)

Pengawasan merupakan tindakan terakhir yang dilakukan para manajer pada suatu organisasi. Siagian berpendapat bahwa pengawasan merupakan proses pengamatan atau pemantauan terhadap pelaksanaan kegiatan organisasi untuk menjamin agar semua pekerjaan yang sedang dilakukan berjalan sesuai dengan rencana yang telah ditentukan sebelumnya. ${ }^{10}$

Dengan pengawasan diharapkan penyimpangan dalam berbagai hal dapat dihindari sehingga tujuan dapat tercapai. Apa yang direncanakan dijalankan dengan benar sesuai hasil musyawarah dan pendayagunaan sumber daya material akan mendukung terwujudnya tujuan organisasi. Pengawasan dimaknai sebagai segala aktivitas untuk

\footnotetext{
${ }^{10}$ Siagian, Filsafat, hlm. 74
}

PROGRESS - Volume 7, No. 1, Juni 2019 
menjamin pencapaian tujuan sebagaimana direncakan dan pemeriksaan terhadap adanya penyimpangan menjadi hakekat pengawasan. Pengawasan ini dapat dilakukan secara langsung maupun pengawasan tidak langsung.

\section{Profesionalisme Guru}

Profesionalisme berasal dari kata profesi yang artinya suatu bidang pekerjaan yang ingin atau akan ditekuni oleh seseorang. Profesionalisme adalah kondisi, arah, nilai, tujuan, dan kualitas suatu keahlian dan kewenangan yang berkaitan dengan mata pencaharian seseorang. Profesionalisme guru merupakan kondisi, arah, nilai, tujuan, dan kualitas suatu keahlian dan kewenanagan dalam bidang pendidikan dan pengajaranyang berkaitan dengan dengan pekerjaan seseorang yang menjadi mata pencaharian.

Profesionalisme adalah komitmen para anggota suatu profesi untuk meningkatkan kemampuan profesionalnya dan terus menerus mengembangkan strategi yang digunakan dalam melakukan pekerjaan sesuai profesinya. Menurut Surya yang dikutip oleh Dadi Permadi profesionalisme guru mengandung pengertian kegiatan atau usaha meningkatakan kompetensi guru ke arah yang lebih baik dilihat dari berbagai aspek demi terselenggaranya satu optimalisasi pelayanan kegiatan atau pekerjaan profesi guru yang memiliki makna penting.

Menurut Sanjaya bahwa sebagai suatu profesi terdapat sejumlah kompetensi yang harus dimiliki oleh seorang guru, yaitu kompetensi pribadi, kompetensi profesional dan kompetensi sosial kemasyarakatan. ${ }^{11}$

\footnotetext{
${ }^{11}$ Sanjaya, Wina, Pembelajaran dalam Implementasi Kurikulum Berbasis Kompetensi, (Jakarta: Kencana Prenada Media Group.2005), hlm. 146

PROGRESS - Volume 7, No. 1, Juni 2019
} 
a. Kompetensi Kepribadian

Dalam Standar Nasional Pendidikan, penjelasan pasal 28 ayat (3) butir $b$, dikemukakan bahwa yang dimaksud dengan kompetensi kepribadian adalah kemampuan kepribadian yang mantap, stabil, dewasa, arif, dan berwibawa, menjadi teladan bagi peserta didik, dan berakhlak mulia. Kompetensi kepribadian sebagaimana dimaksud pada ayat (3) tersebut merupakan kemampuan kepribadian yang mantap, stabil, dewasa, arif dan bijaksana, berwibawa, berakhlak mulia, menjadi teladan bagi peserta didik dan masyarakat. ${ }^{12}$

b. Kompetensi Pedagogik

Kompetensi pedagogik merupakan kemampuan pengelolaan peserta didik yang meliputi: pemahaman wawasan atau landasan kependidikan, pemahaman terhadap peserta didik, pengembangan kurikulum/silabus, perancangan pembelajaran, pelaksanaan pembelajaran yang mendidik dan dialogis, evaluasi hasil belajar, dan pengembangan peserta didik untuk mengaktualisasikan berbagai potensi yang dimilikinya. ${ }^{13}$

c. Kompetensi Profesional

Kompetensi profesional guru adalah sejumlah kewenangan dan kemampuan guru dalam rangka melaksanakan tugas profesinya, meliputi kompetensi sebagai berikut: 1) Menguasai landasan pendidikan, antara lain mengetahui pendidikan (pencapaian kompetensi dasar dan hasil belajar), mengenai fungsi sekolah dalam masyarakat, mengenal prinsip-prinsip psikologi pendidikan yang sangat diperlukan

\footnotetext{
${ }^{12}$ Sembiring, M. Gorky, Mengungkap Rahasia dan Tips Manjur Menjadi Guru Sejati, (Yogyakarta: Percetakan Galangpress, 2009), hlm. 38

${ }^{13}$ Surya, Mohammad, Percikan Perjuangan Guru Menuju Guru Profesional, Sejahtera, dan Terlindungi, (Bandung: Pustaka Bani Quraisy, 2006), hlm. 176

PROGRESS - Volume 7, No. 1, Juni 2019 
dalam proses pembelajaran. 2) Menguasai bahan ajar; menguasai kurikulum pendidikan tahun 2007 (KTSP) dan K-13. 3) Menyusun silabus dan program pembelajaran; menetapkan pencapaian kompetensi dan tujuan pembelajaran, memilih bahan ajar, memilih dan mengembangkan strategi pembelajaran, memilih media pengajaran, memilih dan memanfaatkan berbagai sumber belajar. 4) Melaksanakan acara (program) pembelajaran; menciptakan suasana belajar yang kondusif, mengatur ruang belajar, mengelola interaksi belajar mengajar. 5) Menilai hasil belajar dengan menggunakan sistem penilaian berbasis kelas. $^{14}$

d. Kompetensi Sosial Kemasyarakatan

Kompetensi sosial merupakan kemampuan pendidik sebagai bagian dari masyarakat untuk: berkomunikasi lisan dan tulisan; menggunakan teknologi komunikasi dan informasi secara fungsional; bergaul secara efektif dengan peserta didik, tenaga kependidikan, orang tua/wali peserta didik dan bergaul secara santun dengan masyarakat sekitar. $^{15}$

C. PEMBAHASAN PENELITIAN

1. Manajemen Lembaga Pendidikan Islam Dalam Meningkatkan Profesionalisme Guru

Dalam rangka mencapai tujuan sekolah, lembaga pendidikan Islam memiliki wewenang mengatur dan mengelola empat hal pokok yaitu: manajemen kurikulum, manajemen sumber daya manusia, manajemen kesiswaan, manajemen keuangan dan manajemen sarana

\footnotetext{
${ }^{14}$ Surya, Mohammad, Percikan Perjuangan Guru Menuju Guru Profesional, Sejahtera, dan Terlindungi, (Bandung: Pustaka Bani Quraisy, 2006), hlm. 176

${ }^{15}$ Ibid, hlm. 176

PROGRESS - Volume 7, No. 1, Juni 2019 
prasarana sekolah. Keempat hal ini menurut peneliti terkait langsung dengan peningkatan profesionalisme guru.

a. Manajemen Kurikulum

Penerapan perencanaan di SMP IT Darussalam Sragen sudah berjalan sebagai mana mestinya dimana proses penyusunan rencana melalui musyawarah yang melibatkan semua komponen madrasah (komite madrasah, urusan tata usaha, dan para guru) yang kemudian memberikan kepercayaan kepada tim untuk menyusun dan ditetapkan pada rapat komite sekolah. Makna yang muncul dari perilaku pengambilan keputusan sebagaimana dikemukakan di atas adalah pengambilan keputusan dilakukan secara konsultatif, partisipatif dan delegatif.

Kegiatan belajar mengajar merupakan inti dari proses pendidikan di SMP IT Darussalam Sragen, guru berperan sebagai pelaksana dan pengembang utama kurikulum di sekolah. Dengan demikian pemahaman terhadap kurikulum sampai dengan strategi pelaksanaan adalah sangat penting. Meskipun kegiatan pembelajaran di kelas/laboratorium/ lapangan dilaksanakan oleh guru, tetapi peran lembaga sangatlah penting mulai dari perencanaan, koordinasi pelaksanaan, sampai evaluasi. Lembaga pendidikan yang menunjukkan komitmen tinggi dan fokus terhadap pengembangan kurikulum dan kegiatan belajar mengajar di sekolahnya tentu saja akan sangat memperhatikan tingkat kompetensi yang dimiliki gurunya, sekaligus juga akan senantiasa berusaha memfasilitasi dan mendorong agar para guru dapat secara terus menerus meningkatkan kompetensinya, sehingga kegiatan belajar mengajar dapat berjalan efektif dan efisien. 
Perencanaan dan pengembangan kurikulum nasional pada umumnya telah dilakukan oleh Departemen Pendidikan Nasional pada tingkat pusat. Karena itu di level sekolah yang paling penting adalah bagaimana merealisasikan dan menyesuaikan kurikulum tersebut dengan kegiatan pembelajaran. Di samping itu, sekolah juga bertugas dan berwenang untuk mengembangkan kurikulum sesuai dengan kebutuhan masyarakat dan lingkungan setempat. Kurikulum yang berlaku sekarang yaitu KTSP (Kurikulum Tingkat Satuan Pendidikan), dalam kurikulum ini terbuka kesempatan kepada pihak sekolah untuk mengambangkan kurikulum standar dari pemerintah sesuai dengan kebutuhan dan keadaan siswa setempat.

b. Manajemen Sumber Daya Manusia

Peranan sumber daya manusia dalam suatu organisasi, termasuk sekolah, sangat penting. Namun sumber daya manusia akan optimal jika dikelola dengan baik. Lembaga memiliki peran sentral dalam mengelola sumber daya manusia di sekolah, sehingga sangat penting bagi kepala sekolah untuk memahami dan menerapkan pengelolaan sumber daya manusia dengan baik. Dalam menerapkan manajemen sumber daya manusia ada 4 prinsip dasar yang dipedomani atau dipegang oleh lembaga pendidikan, yaitu:

1) Dalam mengembangkan sekolah, sumber daya manusia adalah komponen paling berharga.

2) Sumber daya manusia akan berperan secara optimal jika dikelola dengan baik, sehingga mendukung tercapainya tujuan institusional.

3) Kultur dan suasana organisasi di sekolah, serta perilaku manajerial mempengaruhi pencapaian tujuan pengembangan sekolah. 
4) Manajemen sumber daya manusia pada prinsipnya mengupayakan agar setiap warga (guru, staf administrasi, siswa orang tua siswa, dan yang terkait) dapat bekerja sama dan saling mendukung untuk mencapai tujuan sekolah.

Salah satu tugas yang harus dilakukan SMP IT Darussalam Sragen adalah melaksanakan kegiatan pemeliharaan dan pengembangan profesi para guru. Dalam hal ini, lembaga memfasilitasi dan memberikan kesempatan yang luas kepada para guru untuk dapat melaksanakan kegiatan pengembangan profesi melalui berbagai kegiatan pendidikan dan pelatihan, baik yang dilaksanakan di sekolah, seperti: MGMP/MGP tingkat sekolah, in house training, diskusi profesional dan sebagainya, atau melalui kegiatan pendidikan dan pelatihan di luar sekolah, seperti: kesempatan melanjutkan pendidikan atau mengikuti berbagai kegiatan pelatihan yang diselenggarakan pihak lain.

c. Manajemen Kesiswaan

Tolok ukur keberhasilan suatu proses pendidikan dapat dilihat dari out put yang dihasilkan, yaitu melekat pada kualitas lulusan siswa yang dihasilkan dari lembaga tersebut. Agar siswa yang masuk dalam sebuah lembaga pendidikan dapat menguasai kompetensi yang diinginkan oleh orang tua sebagai konsumen dan peningkatan kualitas lembaga pendidikan sebagai produsen, maka diperlukan manajemen kesiswaan yang aplikatif dan dapat memenuhi tuntutan siswa dan orang tua serta sesuai dengan standar sebuah lembaga pendidikan.

Semua kegiatan di SMP IT Darussalam Sragen pada akhirnya ditujukan untuk membantu siswa mengembangkan dirinya. Upaya itu akan optimal jika siswa sendiri secara aktif berupaya mengembangkan 
diri, sesuai dengan program-program yang dilakukan sekolah. Oleh karena itu, sangat penting untuk menciptakan kondisi agar siswa dapat mengembangkan diri secara optimal. Lembaga memegang peranan penting dalam menciptakan kondisi tersebut.

Untuk mengetahui sejauh mana guru mampu melaksanakan pembelajaran, secara berkala kepala SMP IT Darussalam Sragen melaksanakan kegiatan supervisi, hal ini dilakukan melalui kegiatan kunjungan kelas untuk mengamati proses pembelajaran secara langsung, terutama dalam pemilihan dan penggunaan metode, media yang digunakan dan keterlibatan siswa dalam proses pembelajaran. Dari hasil supervisi ini, dapat diketahui kelemahan sekaligus keunggulan guru dalam melaksanakan pembelajaran, tingkat penguasaan kompetensi guru yang bersangkutan, selanjutnya diupayakan solusi, pembinaan dan tindak lanjut tertentu sehingga guru dapat memperbaiki kekurangan yang ada sekaligus mempertahankan keunggulannya dalam melaksanakan pembelajaran.

d. Manajemen Keuangan

Masalah keuangan sangat erat hubungannya dengan pembiayaan, sedangkan masalah pembiayaan itu sendiri merupakan faktor yang sangat penting dan menentukan kehidupan suatu organisasi seperti halnya di SMP IT Darussalam Sragen. Manajemen keuangan sekolah merupakan bagian dari kegiatan pembiayaan pendidikan, secara keseluruhan menuntut kemampuan sekolah untuk merencanakan, melaksanakan dan mengevaluasi serta mempertanggungjawabkan secara akuntabel dan transparan.

Dalam penyelenggaraan pendidikan, keuangan dan pembiayaan merupakan bagian yang tak terpisahkan dalam kajian manajemen 
pendidikan. Komponen keuangan dan pembiayaan pada suatu sekolah merupakan komponen produksi yang menentukan terlaksananya kegiatan-kegiatan proses belajar mengajar (pembelajaran) di sekolah bersama komponen lain. Dengan kata lain, setiap kegiatan yang dilakukan sekolah memerlukan biaya, baik itu disadari maupun tidak disadari. Komponen keuangan dan pembiayaan ini perlu di kelola sebaik baiknya, agar dana-dana yang ada dapat dimanfaatkan secara optimal untuk menunjang tercapainya tujuan pendidikan.

e. Manajemen Sarana dan Prasarana Sekolah

Kegiatan manajemen di SMP IT Darussalam Sragen di bidang sarana dan prasarana yakni mengatur dan menjaga sarana dan prasarana pendidikan agar dapat memberikan kontribusi secara optimal dan berarti pada jalannya proses pendidikan. Secara riil kegiatan kepala sekolah meliputi kegiatan perencanaan, pengadaan, pengawasan, penyimpanan inventarisasi, dan penataan. Manajemen sarana prasarana yang baik diharapkan dapat menciptakan SMP IT Darussalam Sragen yang bersih, rapi, indah sehingga menciptakan kondisi yang menyenangkan baik bagi guru maupun siswa untuk berada di sekolah. Di samping itu juga diharapkan tersedianya alat-alat atau fasilitas belajar yang memadai secara kuantitatif, kualitatif dan relevan dengan kebutuhan serta dapat dimanfaatkan secara optimal untuk kepentingan proses pendidikan dan pengajaran, baik oleh guru sebagai pengajar maupun murid sebagai pelajar.

\section{Profesionalisme Guru di SMP IT Darussalam Sragen}

Profesionalisme Guru di SMP IT Darussalam Sragen dalam Pembelajaran Guru dikatakan profesional bila memiliki kompetensi atau kemampuan mengembangkan dirinya ke arah yang lebih baik. 
Sedikitnya terdapat dua kategori kompetensi yang dimiliki guru, yakni:

(1) kompetensi profesional yaitu kemahiran merancang, melaksanakan, dan menilai tugas sebagai guru, meliputi penguasaan ilmu pengetahuan dan teknologi, (2) kompetensi personal, meliputi etika, moral, pengabdian, kemampuan sosial dan spiritual. Semuanya itu dimiliki oleh guru di SMP IT Darussalam Sragen, diwujudkan dalam bentuk standar dan sertifikasi kompetensi guru. Kompetensi pertama ditumbuhkan dan ditingkatkan melalui proses pendidikan akademik dan profesi suatu lembaga pendidikan. Sedangkan kompetensi kedua merupakan kristalisasi pengalaman dan pergaulan seorang guru, yang terbentuk dalam lingkungan keluarga, masyarakat dan sekolah tempat melaksanakan tugas.

Berdasarkan hasil observasi peneliti, guru di SMP IT Darussalam Sragen terkait dengan kompetensinya memiliki lima hal: (1) mempunyai komitmen pada peserta didik dan proses belajarnya; (2) menguasai secara mendalam bahan/mata pelajaran yang diajarkan kepada peserta didik; (3) bertanggung jawab memantau hasil belajar peserta didik melalui berbagai cara evaluasi, (4) mampu berfikir sistematis tentang apa yang dilakukannya dan belajar dari pengalamannya, (5) seyogyanya merupakan bagian dari masyarakat belajar dalam lingkungan profesinya. Kelima hal tersebut dibuktikan dengan kualitas maupun kuantitas kehadiran guru pada proses belajar mengajar, mempunyai kualifikasi pendidikan yang sesuai, pengisian daftar penilaian siswa dan dapat bersosialisasi serta beradaptasi dengan semua komponen sekolah.

Untuk merealisasikan berbagai kompetensi tersebut guru SMP IT Darussalam Sragen memiliki kemampuan, baik dalam hal teori 
maupun praktek manajemen, karena secara esensial keberadaan guru mempunyai dua fungsi utama dalam proses pembelajaran, yakni: pertama, sebagai administrator yang bertugas melaksanakan fungsi administrasi kelas yang di dalamnya mencakup pengelolaan yang bersifat administratif dan operatif. Kedua, sebagai edukator yang bertugas menjalankan fungsi edukatif dalam proses pembelajaran di kelas.

Lembaga selalu memberikan kepercayaan kepada guru untuk melaksanakan tugasnya melakukan proses belajar mengajar dengan baik. Kepada guru selalu diberikan dorongan dan suasana yang kondusif untuk menemukan berbagai alternatif metode dan cara mengembangkan proses pembelajaran sesuai dengan perkembangan jaman. Agar dapat meningkatkatkan keterlibatannya dalam melaksanakan tugas sebagai guru, dia harus memahami, menguasai dan terampil menggunakan sumber-sumber belajar baru pada dirinya. Sumber belajar bukan hanya guru, apabila guru tidak mampu menyesuaikan diri dengan perkembangan perubahan. Maka guru tersebut akan mudah ditinggalkan oleh muridnya.

Profesionalisme guru SMP IT Darussalam dalam pembelajaran dilaksanakan melalui peningkatan beberapa kompetensi yang dimiliki dan melekat pada dirinya, sehingga tercermin dalam pelaksanaan proses belajar mengajar. Agar kemampuan seorang guru meningkat maka diperlukan upayaupaya dalam rangka menyempurnakan profesionalismenya. Tuntutan aplikasi nilai-nilai ajaran Islam selalu berkembang, apabila guru tidak meningkatkan kemampuannya, dia tidak dapat menjawab tuntutan dan permasalahan yang berkembang di masyarakat. Peningkatan mutu profesionalisme guru yang diterapkan di 
SMP IT Darussalam Sragen dilakukan dengan beberapa cara sebagai berikut:

a. Peningkatan Kualifikasi Pendidikan

Salah satu prinsip pelaksanaan profesi keguruan yang dijabarkan dalam pasal 7 UU 14 tahun 2005 tentang guru dan dosen adalah memiliki kesempatan untuk mengembangkan keprofesionalan secara berkelanjutan dengan belajar sepanjang hayat. Hal ini memiliki pengertian bahwa seorang guru jangan sampai hanya puas dengan ilmu yang sudah dimiliki saja, merasa cukup dengan apa yang sudah dikuasai sekarang. Dalam rangka memberikan pengajaran guru juga harus melakukan pembelajaran dari proses itu, agar menyempurnakan segala kekurangan yang ada.

Selain itu dalam rangka meningkatkan kualitas keprofesionalannya guru juga dituntut untuk meningkatkan jenjang pendidikan yang lebih tinggi, saat sekarang yang disyaratkan oleh pemerintah kualifikasi keguruan adalah apabila seseorang sudah mempunyai ijazah dari LPTK (Setara S-1) atau mempunyai sertifikat akta mengajar. Tidak hanya berhenti sampai jenjang itu saja guru harus dituntut melanjutkan pendidikannya ke jenjang S-2 ataupun S-3. Fenomena yang terjadi dalam keilmuan pendidikan, terutama permasalahan guru dan murid adalah kurangnya motivasi guru untuk mengadakan kajian ataupun penelitian ilmiah dalam konteks pendidikan. Lebih mengena jika guru sendiri yang mengangkat permasalahanpermasalahan pendidikan yang terjadi dalam proses pembelajaran menjadi sebuah kajian ilmiah. Saat ini, berbagai cara dilakukan oleh guru-guru yang mengajar di SMP IT Darussalam Sragen untuk meningkatkan kualitasnya dalam mengajar. 
Usaha ini dilakukan dengan cara mengikuti setiap pelatihan maupun seminar tentang pendidikan, baik yang diadakan oleh sekolah, Dikpora maupun LPTK, dari yang tingkat kabupaten maupun tingkat nasional. Dalam hal pendidikan formal guru SMP IT Darussalam Sragen selalu berusaha untuk mengikuti pendidikan ke jenjang yang lebih tinggi (S-2). Pada saat ini guru yang ada di SMP IT Darussalam Sragen ratarata berkualifikasi sarjana (S-1). Dua guru yang berkualifkasi Magister (S-2) yaitu Wakil Kepala Sekolah dan guru seni budaya. Sedangkan yang masih dalam proses pendidikan untuk jenjang Magister (S-2) ada tiga guru, meliputi kepala sekolah, guru IPA dan guru PAI. Rencananya untuk tahun ajaran yang akan datang ada dua guru lagi yang akan mendaftarkan untuk mengikuti studi Magister. ${ }^{16}$

b. Aktif dalam Organisasi Keguruan

Saat ini organisasi yang dapat menampung aspirasi guru dan meningkatkan kualitas guru adalah forum musyawarah guru mata pelajaran (MGMP), baik ditingkat sekolah maupun ditingkat kabupaten. Setiap awal tahun ajaran baru guru yang bersangkutan selalu membuat program MGMP di tingkat sekolah maupun di tingkat kabupaten. Ditingkat sekolah tentunya dilakukan oleh guru yang mengajar mata pelajaran yang serumpun seperti PAI dengan Bahasa Arab. Diprogramkan ditingkat sekolah sebanyak dua kali dalam sebulan, sedangkan di tingkat kabupaten setiap hari rabu diadakan acara MGMP. Dengan mengikuti kegiatan dalam forum MGMP tersebut akan menambah wawasan dalam pengetahuan tentang pembelajaran maupun pengetahuan pendukung dan tahu akan kekurangannya untuk berusaha mengejar ketinggalan dalam rangka meningkatkan kualitasnya. Di

\footnotetext{
${ }^{16}$ Wawancara dengan Waka Kurikulum, 25 September 2018
} 
samping itu dapat mempermudah dalam melakukan pekerjaan terkait dengan masalah pembelajaran.

c. Uji Kompetensi Guru

Sesuai dengan pendapat Mulyasa bahwa untuk meningkatkan kualitas guru, perlu dilakukan suatu sistem pengujian terhadap kompetensi guru. Secara nasional dapat dilakukan oleh pemerintah pusat untuk mengetahui kualitas dan standar kompetensi guru, terkait dengan pembangunan pendidikan secara keseluruhan. Begitu halnya yang dilakukan oleh guru SMP IT Darussalam Sragen setiap tiga tahun selalu aktif mengikuti uji kompetensi dalam rangka kenaikan pangkat atau golongan. Persiapan yang dilakukan adalah membuat perangkat pembelajaran secara rutin dan tertib, melaksanakan penilian beserta analisisnya, mengikuti kegiatan-kegiatan pendidikan, membuat modul dan media pembelajaran, membuat power point dan membuat contoh praktek pembelajaran dan sebagainya. ${ }^{17}$

d. Peningkatan Kesejahteraan

Pemerintah mulai tahun 2007 berusaha mensejahterakan para guru dan tenaga pendidikan sesuai dengan Undang-undang nomor 14 tahun 2005 tentang guru dan dosen, dinyatakan bahwa setelah guru dinyatakan lolos dalam uji kompetensi dan mendapatkan sertifikat guru profesional dari lembaga yang ditunjuk pemerintah, maka guru berhak mendapatkan tunjangan yang besarnya satu kali gaji pokok. Dana sertifikasi bersumber dari dana APBN ataupun APBD. Pelaksanaan sertifikasi sesuai dengan peraturan Menteri Pendidikan Nasional Nomor 18 tahun 2007, bagi guru prajabatan dilakukan melalui pendidikan profesi di LPTK yang terakreditasi dan ditetapkan pemerintah diakhiri

\footnotetext{
${ }^{17}$ Wawancara dengan Kepala Sekolah, 19 Oktober 2018
} 
dengan ujikompetensi. Sedangkan untuk sertifikasi guru dalam jabatan dilakukan dalam bentuk portofolio.

Kebijakan SMP IT Darussalam Sragen selalu berusaha untuk mensejahterakan guru dan karyawannya dengan tidak terlalu membani orang tua peserta didik. Terutama bagi guru dan karyawan yang statusnya masih GTT atau PTT, karena mereka hanya mendapatkan gaji dari sekolah saja ditambah sedikit dari pemerintah daerah. Bagi guru yang sudah PNS kepala sekolah tetap memberikan tambahan sesuai dengan kapasitasnya dengan syarat seperti yang sudah diatur dan tidak menyalahi aturan dari pemerintah. Seperti guru akan mendapatkan kesejahteraan tambahan apabila mengajar lebih dari jumlah jam yang diwajibkan yaitu 24 jam pelajaran atau disebut kelebihan jam mengajar (KJM). Selain itu guru yang sudah PNS akan mendapatkan tunjangan apabila melaksanakan tugas tambahan seperti: wakil kepala sekolah, staf dan pembina kegiatan yang lain. ${ }^{18}$

\section{KESIMPULAN}

Berdasarkan paparan data dan temuan penelitian di lapangan serta hasil pembahasan penelitian yang difokuskan pada manajemen lembaga pendidikan Islam dalam peningkatan profesionalisme guru di SMP IT Darussalam Sragen menghasilkan kesimpulan sebagai berikut:

Peningkatan profesionalisme guru di SMP IT Darussalam Sragen tidak dapat dilakukan dengan sendirinya, butuh dukungan dan kesempatan dari kepala sekolah dan beberapa pihak yang terkait. Manajemen lembaga pendidikan Islam dalam meningkatkan profesionalisme guru di SMP IT Darussalam Sragen tidak terlepas dari kegiatan manajemennya baik dalam bidang kurikulum, sumber daya

\footnotetext{
${ }^{18}$ Wawancara dengan Kepala Sekolah, 30 Oktober 2018
} 
manusia, kesiswaan, keuangan dan sarana prasarana. Hal ini terlihat dalam proses manajemen, dimana kepala sekolah bersama seluruh komponen lembaga telah berusaha melakukan perencanaan, pengorganisasian, penggerakan dan supervisi (evaluasi) kepada guruguru, dengan melibatkan wakil-wakilnya (kurikulum, kesiswaan, sarana prasarana dan humas).

Peningkatan profesionalisme guru SMP IT Darussalam Sragen dilaksanakan melalui empat kompetensi guru, yaitu kompetensi pribadi, kompetensi pedagogik, kompetensi sosial dan kompetensi profesional. Keempat kompetensi tersebut dilaksanakan secara bersinergi, saling menyempurnakan dalam semua aktifitas guru di sekolah. Komitmen lembaga pendidikan untuk memajukan pendidikan melalui perencanaan dan program peningkatan profesionalisme guru. Kepala sekolah sebagai penyelenggara pendidikan berkewajiban untuk membantu para guru dalam meningkatkan profesionalnya, dengan berbagai macam cara, misalnya dengan meningkatkan kualitas akademik, mengikutsertakan guru dalam pendidikan profesi, dan juga dalam program sertifikat guru dan yang lainnya yang bertujuan untuk menjadikan guru benar-benar menjadi profesional dalam melaksanakan tugasnya. Namun demikian, kompetensi yang dimiliki guru SMP IT Darussalam Sragen saat ini masih belum sampai dalam taraf sempurna, masih perlu adanya pembenahan dan peningkatan kompetensi tersebut. Karena pada dasarnya kompetensi guru selalu dinamis, berkembang sesuai dengan kebutuhan, kondisi dan tuntutan pendidikan, dengan permasalahan keagamaan yang selalu berkembang. 


\section{DAFTAR PUSTAKA}

Anggota IKAPI, 2011. Undang-Undang RI Nomor 20 Tahun 2003 tentang Sisdiknas \& Peraturan Pemerintah RI Tahun 2010 tentang Penyelenggaraan Pendidikan serta Wajib Belajar, Bandung: Citra Umbara

Cece Wijaya dan A. Tabrani Rusyan, 1999. Kemampuan Dasar Guru dalam Proses Belajar Mengajar, Bandung: Remaja Rosdakaiya.

Fattah, Nanang.2013. Landasan Manajemen Pendidikan, Bandung: Remaja Rosda Karya.

Hamzah B. 2009. Profesi Kependidikan: Problema, Solusi dan Reformasi Pendidikan di Indonesia, Jakarta: Bumi Aksara.

Hasbullah, 2015. Kebijakan Pendidikan dalam Perspektif Teori Aplikasi dan

Kondisi Objektif Pendidikan di Indonesia, Jakarta: PT Raja Grafindo Persada Husaini Usman, 2009. Manajemen : Teori, Praktek dan Riset Pendidikan, Jakarta: Bumi Aksara

Iqbal Fahri, Madrasah Unggulan dalam Tinjauan (Artikel PDF)

Iskandar Agung, 2014. Mengembangkan Profesionalitas Guru, Jakarta: Bee Media Pustaka.

Muhaimin dan Abdul Mujib, 1993. Pemikiran Pendidikan Islam, Bandung: Triganda Karya.

Muhaimin, 1997. Eksistensi Madrasah sebagai madrasah Umum yang berciri khas Islam, Malang: IAIN Tarbiyah

Mujamil Qomar, 2013. Strategi Pendidikan Islam, Jakarta: Erlangga

Mulyasa, E., 2008. Standar Kompetensi dan Sertifikasi Guru, Bandung: PT Remaja Rosdakarya 
Muslich, Masnur, 2007. Sertifikasi Guru Menuju Profesionalisme Pendidik, Jakarta: Bumi Aksara

Nana Syaodah Sukmadinata, 2006. Metode Penelitian Pendidikan, Bandung: PT. Remaja Rosdakarya.

Prim Masrokan Mutohar, 2014. Manajemen Mutu Sekolah; Strategi Peningkatan Mutu dan Daya Saing Lembaga Pendidikan Islam, Cet. II, Jogjakarta: Ar-Ruzz Media.

S. Nasution 2001., Metode Research (Penelitian Ilmiah). Jakarta: Bumi Aksara.

S. Shoimatul Ula, 2013. Buku Pintar Teori-Teori Manajemen Pendidikan Efektif, Jogjakarta: Berlian

Sanjaya, Wina, 2005. Pembelajaran dalam Implementasi Kurikulum Berbasis Kompetensi, Jakarta: Kencana Prenada Media Group

Sembiring, M. Gorky, 2009. Mengungkap Rahasia dan Tips Manjur Menjadi Guru Sejati, Yogyakarta: Percetakan Galangpress

Siagian, 2006. Filsafat Administrai.Edisi Revisi. Jakarta: Bumi Aksara

Sondang. P. Siagian, 1985. Filsafat Administrasi, Jakarta: Gunung Agung

Sri Hartati, 2015. Kompetensi dan Profesionalisme Guru, Al-Wafa' Jurnal Pendidikan Sosial dan Keagamaan

Sugiyono, 2008. Metode Penelitian Pendidikan, Pendekatan Kuantitatif, Kualitatif dan $R \& D$ Bandung: Alfabeta

Suharsimi Arikunto, 1995.Prosedur Penelitian Suatu Pendekatan Praktek, Jakarta: Rineka Cipta

Surya, Mohammad, 2006. Percikan Perjuangan Guru Menuju Guru Profesional, Sejahtera, dan Terlindungi, Bandung: Pustaka Bani Quraisy 
Surya, Mohammad, 2006. Percikan Perjuangan Guru Menuju Guru Profesional, Sejahtera, dan Terlindungi, Bandung: Pustaka Bani Quraisy,

Syamsul Ma'arif, 2011. Guru Profesional Harapan dan Kenyataan, Semarang: Walisongo Press

T.Hani Handoko, 2011. Manajemen Edisi 2, Yogyakarta: Anggota IKAPI

Winardi, 1990. Dasar-Dasar Manajemen, Bandung: Sinar Baru 